\title{
Anxious interactions
}

\author{
Javier González-Maeso \\ Departments of Psychiatry and Neurology, Mount Sinai School of Medicine, New York, New York, \\ USA
}

Javier González-Maeso: javier.maeso@mssm.edu

\begin{abstract}
The molecular mechanisms responsible for anxiety remain largely unresolved. A study in this issue finds that an interaction between receptors for a hormone and a neurotransmitter regulates anxiety.
\end{abstract}

Fear is an important evolutionary force. Animals need to distinguish between different environmental factors and respond to aversive situations in a way that maximizes their chance of survival and that of their offspring. Normally, a fearful state protects us from potential danger or threat. In humans, however, certain environmental cues, such as being asked to give a speech in front of others, are able to trigger lasting behavioral changes that can be converted into maladaptive, pathological fear and anxiety. Giving a speech in front of an audience typically generates states of fear and normal anxiety, but those disappear once the talk has been completed. People with anxiety disorder ${ }^{1}$, on the contrary, find it almost impossible to accomplish this task and have pathological anxiety states in response to even the suggestion of being invited to give an oral presentation. Unfortunately, we don't have a clear understanding of why this happens. The absence of clear pathological alterations in the brain of individuals with psychiatric disorders, such as anxiety and depression, is currently one of the most challenging aspects of neuroscience research. The quest to uncover these changes has led to the development of a multitude of hypotheses, many of which are focused on a single hormone or neurotransmitter. In this issue, Magalhaes et al. ${ }^{2}$ connect two signaling systems that have been separately implicated in anxiety behaviors, finding that the two interact to induce anxiety.

Both the neurotransmitter serotonin and the hormone corticotropin-releasing factor (CRF) have been implicated in the molecular underpinnings of anxiety disorders. Serotonin modulates behavioral responses to novelty and threat ${ }^{1}$. Antidepressants with anxiolytic properties, such as mirtazapine, act, at least in part, by blocking the activation of the serotonin $5-\mathrm{HT}_{2 \mathrm{~A}}$ receptor ${ }^{3}$, and mice that lack a functional $5-\mathrm{HT}_{2 \mathrm{~A}}$ receptor ${ }^{4}$ have reduced anxiety-like behaviors. These observations suggest that serotonin, and particularly the 5$\mathrm{HT}_{2 \mathrm{~A}}$ receptor, is important in the etiology of anxiety and in the response to anxiolytic drugs. When CRF was first discovered in the hypothalamus ${ }^{5}$, its modulation of the behavioral responses to stress was thought to be restricted to the regulation of hormone secretion by the hypotha-lamic-pituitary-adrenal axis. However, CRF receptors are widely expressed in different brain regions and regulate physiological responses in both anxiety states and behavioral mechanisms of defense ${ }^{6}$. Drugs that block the activation of $\mathrm{CRF}_{1}$ receptor act as anxiolytic agents ${ }^{7}$.

(C) 2010 Nature America, Inc. All rights reserved.

COMPETING FINANCIAL INTERESTS

The author declares no competing financial interests. 
Both 5- $\mathrm{HT}_{2 \mathrm{~A}}$ and $\mathrm{CRF}_{1}$ receptors belong to the superfamily of $\mathrm{G}$ protein-coupled receptors $(\mathrm{GPCRs})^{8}$, also termed seven-transmembrane receptors. This structural class of membrane proteins is the target of approximately $60 \%$ of the current therapeutic drugs in the market, including more than a fourth of the 100 top-selling drugs. A central question in biology today is how the cell integrates information from multiple receptors to achieve the appropriate response. Magalhaes $e t \mathrm{al}^{2}{ }^{2}$ wondered whether a functional link exists between 5- $\mathrm{HT}_{2 \mathrm{~A}}$ and $\mathrm{CRF}_{1}$ receptors that might affect anxiety-like behaviors in mice. The 5-HT2A receptor is typically coupled to $\mathrm{Gq} / 11$ proteins, which leads to the hydrolysis of a phospholipid component at the plasma membrane followed by the generation of diacylglycerol and inositol triphosphate (IP3). Magalhaes and colleagues ${ }^{2}$ found that activation of $\mathrm{CRF}_{1}$ receptor potentiates the IP3 formation in response to $5-\mathrm{HT}_{2 \mathrm{~A} / 2 \mathrm{C}}$ receptor stimulation. This effect is not observed with the activation of the closely related $\mathrm{CRF}_{2}$ receptor, indicating that the functional crosstalk between $5-\mathrm{HT}_{2} \mathrm{~A} / 2 \mathrm{C}$ and $\mathrm{CRF}_{1}$ receptors is specific. In unstimulated cells, the rate of GPCR endocytosis from the plasma membrane into intracellular vesicles is relatively slow and this rate is markedly increased by agonist activation ${ }^{9}$. However, and in contrast with what is observed for most of the GPCR subtypes, the $5-\mathrm{HT}_{2 \mathrm{~A} / 2 \mathrm{C}}$ receptor has a high rate of basal internalization ${ }^{10}$. Magalhaes et al. ${ }^{2}$ found that activation of $\mathrm{CRF}_{1}$ receptor markedly increases its rate of endocytosis and that $5-\mathrm{HT}_{2} \mathrm{~A}$ colocalizes with $\mathrm{CRF}_{1}$ in the same intracellular membrane compartments. Once the receptors have been internalized, they can either be recycled back to the plasma membrane or directed to lysosomes for degradation ${ }^{11}$. Magalhaes and colleagues' findings ${ }^{2}$ suggest that activation of $\mathrm{CRF}_{1}$ receptor increases the expression of 5- $\mathrm{HT}_{2 \mathrm{~A}}$ receptor at the cell surface and that inhibition of rapid recycling of receptors from early endosomes to the plasma membrane blocks the potentiation of 5- $\mathrm{HT}_{2 \mathrm{~A}}$ receptor-dependent signaling by $\mathrm{CRF}_{1}$ receptor activation. The intracellular tails of the two receptors are necessary for this functional interaction ${ }^{2}$, as deletion of the last three amino acids results in the reduction of the effects of $\mathrm{CRF}_{1}$ activation on 5- $\mathrm{HT}_{2 \mathrm{~A}}$ signaling and cell surface expression (Fig. 1).

Finally, Magalhaes et al. ${ }^{2}$ found a behavioral interaction between $5-\mathrm{HT}_{2 \mathrm{~A}}$ and $\mathrm{CRF}_{1}$ receptors in mouse models of anxiety disorders. Although they often occur together, anxiety and major depression are considered to be two distinct psychiatric disorders. An emerging approach to better understand the mechanisms underlying depression and anxiety is the development of mouse behavioral procedures that model the symptoms of only one of the two disorders ${ }^{12}$. Mouse models of anxiety disorder include the open field exploration test and elevated plus-maze ${ }^{13}$. The open field is a large square chamber that allows the mouse to choose between the unprotected center of the arena and the safety of the corners. Mice that spend more time exploring the novelty of the center area demonstrate less anxiety-like behavior. The elevated plus-maze has two unprotected arms (open without sidewalls) and two protected arms (closed with sidewalls). Mice tend to avoid the open areas, especially when they are brightly lit. An increase in open arm activity reflects less anxiety-like behavior. The authors ${ }^{2}$ found that the center time in an open field and the latency to enter open arms in the plus-maze test are not affected by low doses of either CRF or the 5-

$\mathrm{HT}_{2 \mathrm{~A} / 2 \mathrm{C}}$ receptor agonist 2,5-dimethoxy- 4-iodoamphetamine (DOI) when administered separately. Simultaneous administration of CRF in frontal cortex with DOI exacerbates anxiety-related behaviors ${ }^{2}$, an effect that is blocked by a selective $5-\mathrm{HT}_{2 \mathrm{~A}}$ receptor antagonist, further supporting the notion of a $5-\mathrm{HT}_{2 \mathrm{~A}}-\mathrm{CRF}_{1}$ interaction.

Magalhaes and colleagues' findings ${ }^{2}$ may help to unify the serotonergic and CRF hypotheses of anxiety disorders. It would be reasonable to speculate that both $5-\mathrm{HT}_{2 \mathrm{~A}}$ and $\mathrm{CRF}_{1}$ receptor antagonists present anxiolytic effects because they affect the function of the $5-\mathrm{HT}_{2 \mathrm{~A}}-\mathrm{CRF}_{1}$ protein complex. This hypothesis could be tested by comparing anxiety-like behaviors in mice in which the functional interplay between $5-\mathrm{HT}_{2} \mathrm{~A}$ and $\mathrm{CRF}_{1}$ receptors has been abolished. Before the early 2000s, GPCRs were believed to be expressed at the cell 
membrane as individual monomeric units. A number of findings in the last decade support the hypothesis that GPCRs are expressed as homo- and hetero-dimers or even higher-order oligomers that modulate their function and ligand pharmacology ${ }^{14}$, yet the transmembrane domains are generally responsible for this type of receptor complex formation. Several studies have also revealed that many intracellular soluble proteins interact directly or indirectly, via scaffolding proteins, with intracellular C-terminal tails of GPCRs and control their trafficking and signaling ${ }^{15}$. A new mechanism of interaction between two membrane receptors that requires their intracellular tails and affects cell surface expression opens a line of research to explore not only the biophysical properties of that heteromeric protein complex, but also the molecular explanation for anxiety.

\section{References}

1. Gross C, Hen R. Nat Rev Neurosci. 2004; 5:545-552. [PubMed: 15208696]

2. Magalhaes AC, et al. Nat Neurosci. 2010; 13:622-629. [PubMed: 20383137]

3. Croom KF, et al. CNS Drugs. 2009; 23:427-452. [PubMed: 19453203]

4. Weisstaub NV, et al. Science. 2006; 313:536-540. [PubMed: 16873667]

5. Vale W, et al. Science. 1981; 213:1394-1397. [PubMed: 6267699]

6. Arzt E, Holsboer F. Trends Pharmacol Sci. 2006; 27:531-538. [PubMed: 16935354]

7. Valdez GR. CNS Drugs. 2006; 20:887-896. [PubMed: 17044726]

8. Rosenbaum DM, et al. Nature. 2009; 459:356-363. [PubMed: 19458711]

9. Koenig JA, Edwardson JM. Trends Pharmacol Sci. 1997; 18:276-287. [PubMed: 9277131]

10. Lopez-Gimenez JF, et al. Mol Pharmacol. 2008; 74:1278-1291. [PubMed: 18703670]

11. Sorkin A, Von Zastrow M. Nat Rev Mol Cell Biol. 2009; 10:609-622. [PubMed: 19696798]

12. Kalueff AV, et al. Behav Brain Res. 2007; 179:1-18. [PubMed: 17306892]

13. Cryan JF, Holmes A. Nat Rev Drug Discov. 2005; 4:775-790. [PubMed: 16138108]

14. Milligan G. Br J Pharmacol. 2009; 158:5-14. [PubMed: 19309353]

15. Gavarini S, et al. Biol Cell. 2004; 96:373-381. [PubMed: 15207907] 


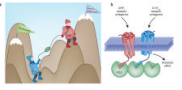

Figure 1.

Biochemistry of anxiety. (a) The $\mathrm{CRF}_{1}$ receptor 'helps' the 5- $\mathrm{HT}_{2 \mathrm{~A}}$ receptor climb up from the endosome to the plasma membrane where its cellular signaling leads to symptoms of anxiety. (b) $\mathrm{CRF}_{1}$ and 5- $\mathrm{HT}_{2 \mathrm{~A}}$ receptors are colocalized and form part of a protein complex in individual cortical neurons. Agonist-induced $\mathrm{CRF}_{1}$ receptor internalization is followed by 5- $\mathrm{HT}_{2 \mathrm{~A}}$ receptor recycling to the plasma membrane and a higher 5- $\mathrm{HT}_{2 \mathrm{~A}}$ receptordependent signaling response. The last three amino acids of their PDZ-binding motifs mediate the functional interaction between $\mathrm{CRF}_{1}$ and 5- $\mathrm{HT}_{2 \mathrm{~A}}$ receptors. From these findings, it can be hypothesized that the anxiolytic properties of both $\mathrm{CRF}_{1}$ and $5-\mathrm{HT}_{2 \mathrm{~A}}$ receptor antagonists require the expression of cortical $\mathrm{CRF}_{1}$ and $5-\mathrm{HT}_{2 \mathrm{~A}}$ receptors in the same protein complex. 